\title{
Online Counselling: Application of Cognitive Behaviour Therapy and Music Counselling to Reduce Math Anxiety
}

\author{
Andreas Wisnu Adi Purnomo, J. T. Loekmono
}

Universitas Kristen Satya Wacana, Salatiga, Indonesia

Email Address: andreaswisnu55@gmail.com

Submitted : 23-12-2020, Revised : 17-04-2021, Accepted : 29-05-2021

\begin{abstract}
Math anxiety is one of the causes of the low achievement of students in mathematics lessons. Guidance and counselling teachers need strategies for students who experience math anxiety. This study aims to determine an effective counselling approach to reduce students' math anxiety. This type of research is a single subject experiment with multiple baseline designs. The sampling technique used was purposive sampling. The research subjects were 2 individuals. The data analysis technique consisted of data analysis using Mann Whitney and qualitative time triangulation techniques. Based on the research results, cognitive behaviour therapy and music counselling can reduce students' math anxiety. Several techniques in cognitive behaviour therapy affect many aspects such as feelings, thoughts, physical sensations, and actions. In music counselling, the lyrics and lyrics of the songs shift the focus of the individual who was originally fixated on the fear of facing math problems to become calmer during math lessons.
\end{abstract}

Keywords: Cognitive Behaviour Therapy; Music Counseling; Math Anxiety; Online Learning.

\section{Introduction}

The development of mathematics learning in Indonesia is still very concerning. This can be seen from the ability of each student whose learning outcomes are still much below average. This happens because they perceive mathematics as a difficult and unpleasant subject. This is certainly an alarm for every education staff to make students rank better. In addition, based on the results of the 2015 Trend in International Mathematics and Science Study research, it was found that mathematics is a frightening specter for most students in Indonesia, this can be seen from the students' mastery of mathematics subject matter (Prahara, 2017).

One of the factors causing suboptimal mathematics achievement is the anxiety experienced by students related to the lesson. Based on research that examines the effect of math anxiety on mathematical learning outcomes, shows that the results of math anxiety have a negative impact on mathematics learning achievement of students in Senior High School Sukabumi, West Java (Ikhsan, 2019). Then, research studies that examine the effect of mathematical anxiety and self-concept on student mathematics learning outcomes, found that there is a significant effect of math anxiety on student mathematics learning outcomes, where students who have high math anxiety tend to have low mathematics learning achievement (Juliyanti \& Pujiastuti, 2020).

Seeing this, of course, becomes an urgency for Guidance and Counseling service personnel to overcome math anxiety which is one of the factors for the low mathematics achievement of students. Moreover, mathematics is one of the sciences that plays an important role in the development of technology, therefore in order to improve the country's technological progress, students' mastery of mathematics is one of the keys to technological advancement in Indonesia. Guidance and counselling play an important role, namely providing counselling services for students who experience math anxiety. Based on a preliminary study conducted by researchers, out of 78 students from the Diponegoro Vocational High School class, Salatiga, 29 individuals were in the moderate math anxiety category, 10 individuals were in the rather high category of math anxiety, and 5 were in the high category, and the rest were in the category of moderate math anxiety. rather low and, 
low. A total of 50 students were in the moderate to high math anxiety category. These results indicate Diponegoro Vocational High School, Salatiga students on average experience math anxiety. In addition, based on the results of interviews with several randomly selected students, the students concerned expressed less enthusiasm when they had to take mathematics lessons. Apart from the fact that there are quite a lot of tasks, the factor of the difficulty of the material to be mastered makes them not enthusiastic. Some even feel the impact physically, such as dizziness, nausea, and loss of energy when taking math lessons. Reviewing the function of guidance and counselling, one of which is the function of healing (Yusuf \& Nurihsan, 2019), then the counselling teacher has the duty to provide counselling services in order to alleviate the psychological problems experienced by their students.

Strategies that can be used to reduce math anxiety experienced by students include providing counselling services. From several strategies in counselling, it is necessary to carry out an assessment to determine the comparison of the effectiveness of a counselling model that is more effective and significant in reducing math anxiety experienced by students (McLeod, 2016). By obtaining the results of a comparison between one approach and another to overcome math anxiety, it is hoped that it will make it easier for BK service personnel to choose the right counselling approach for students experiencing these disorders. Moreover, in 2020 the learning process must be done remotely with network media. Therefore, counselling services must also shift from conventional ones to cyber-based counselling services in order to remain effective during a pandemic.

Cognitive behaviour therapy and music counselling are two different models of counselling. Cognitive behaviour therapy is counselling that is included in the cognitivebehavioural stream (McLeod, 2016), and music counselling enter into the stream of the art of counselling (Odell Miller, 2019). Both counselling is used as a solution to reduce anxiety. This is because the anxiety that occurs in students comes from irrational thoughts, besides the cause of the low interest of students in mathematics lessons, namely the learning atmosphere that is less pleasant and even tends to be frightening. Therefore, both counselling strategies are considered biased to reduce student anxiety in mathematics. This statement is supported by research which states that cognitive behavioural therapy with self-management techniques can significantly reduce students' math anxiety levels (Putri, 2018). Supported by music counselling research to reduce students' math anxiety class significantly (Susanti and Rohmah,2012). Then another study conducted music counselling on elementary students who had math lessons, the result was that music counselling reduced anxiety in facing elementary students' mathematics lessons (Tarigan, 2016). Supported by research that measures the correctness of behaviour to reduce the number of junior high school students, it will decrease from medium to low (Bazargan and Amiri, 2018). Another study used a meta-analysis approach, to test the effects of cognitive behavior therapy (CBT) as a clinically based treatment of students' math anxiety. This study shows the results, cognitive behavioural counselling has a significant effect on reducing students' math anxiety (Mozart. Bicer, Perihan, and Lee, 2020).

Referring to the results of previous studies that have been described, it is known that both cognitive behaviour therapy and music counselling show significant results in reducing math anxiety. However, the effectiveness of a counselling approach is not only based on a significant reduction in the level of disturbance before receiving treatment with conditions after receiving treatment. The effectiveness of a counselling approach needs to look at the variable duration of the disorder recurrence after the subject does not receive treatment and also the working alliance that is built between the counsellor and the counselee during the counselling session (McLeod, 2016). From previous research, only the criteria for the effectiveness of the treatment were given, which was based on a significant reduction in the disturbance experienced by the subject after the subject had finished the treatment period. 
Apart from the aspect of the effectiveness criteria that the researchers feel is the weakness of these studies. The implementation process of the counselling process is carried out using conventional methods, where the counsellor meets face to face with the counselee. Whereas in the topic that the researchers studied, using online or network media assisted by the Whatsapp Video Call (VC) application (WA) in the implementation of the counselling experiment. The background of using the VC WA application, because WA is an application that is popularly used by the public, besides that the cost of using the internet quota is relatively affordable compared to other applications, for example zoom. So far there has been no research that examines the same topic as this study. Therefore, researchers are interested in comparing the effectiveness of cognitive behaviour therapy and music counselling to reduce students' math anxiety.

\section{Methods}

This research approach is quantitative with a single-subject experimental type. The single-subject experimental design used is the plural baseline. The research implementation began with a pre-test on the research subject 3 times in 3 different periods of time. After going through the pre-test and the subject is declared fit for treatment, the next step is giving treatment. The treatment for cognitive behaviour therapy consisted of 7 sessions, while music counselling consisted of 6 sessions. The difference in the number of sessions refers to the competency standards that must be mastered for each approach. Researchers measured the level of math anxiety using test and interview instruments in 3 different time periods, in order to find out how long the therapeutic effect was on subjects who had not received treatment.

The population in this study were students of class XI, the Marketing Department of Vocational High School Diponegoro, Salatiga. The sampling technique used in this study was the purposive sampling technique. Individuals who were research subjects were class XI students majoring in marketing with relatively the same level of math anxiety. In addition, in terms of socio-economic aspects, the two subjects are the merchant family. The variables in this study consisted of cognitive behaviour therapy and music counselling as independent variables and mathematics anxiety as the dependent variable. Meanwhile, the effectiveness criteria which consisted of the duration of the recurrence and the quality of the work alliance in this study were moderate variables that also determined the effectiveness of the counselling treatment given.

In this study, researchers used questionnaires and interviews in retrieving data. The questionnaire consists of the Abbreviate Mathematic Scale (AMAS) and Works Alliance Inventory Short Revision (WAI-SR). AMAS instrument adapted from Hopko, Mahadevan, Bare, and Hunt (2003) while for WAI-SR it was adapted from Munder, Wilmers, Leonhart, Linster, and Barth (2010).

The analytical technique used in this study is the mixed method, which consists of statistical and qualitative analysis. Statistical analysis used the One sample t-test and the Mann Whitney test. The formula for One sample t-test is used to test differences in math anxiety levels in the pre-test period. This is because the pre-test on the subject was carried out 3 times in 3 different periods in order to conclude that the subject was actually experiencing math anxiety and was worthy of being the subject of research. While the Mann Whitney formula is used to test the effect of treatment before the subject receives treatment with a treatment period and a period without treatment. Then for qualitative analysis using the time triangulation technique, in which this technique is used to validate the results of interviews conducted when the subject was without treatment. In statistical analysis, this study uses the help of the application Statistics Product for Service Solution version 16.0 


\section{Results and Discussion}

Based on the implementation of the experiment from the pre-test stage to the post-test stage, a description of the level of anxiety of the research subjects was found as follows:

Table 1. Math Anxiety Level

\begin{tabular}{|c|c|c|c|c|c|c|c|c|c|c|c|c|c|}
\hline & $\begin{array}{c}\text { Pre } \\
1\end{array}$ & $\begin{array}{c}\text { Pre } \\
2\end{array}$ & $\begin{array}{c}\text { Pre } \\
\mathbf{3}\end{array}$ & $\begin{array}{c}\text { Session } \\
1\end{array}$ & $\begin{array}{c}\text { Session } \\
2\end{array}$ & $\begin{array}{c}\text { Session } \\
\mathbf{3}\end{array}$ & $\begin{array}{c}\text { Session } \\
4\end{array}$ & $\begin{array}{c}\text { Session } \\
5\end{array}$ & $\begin{array}{c}\text { Session } \\
6\end{array}$ & $\begin{array}{c}\text { Session } \\
7\end{array}$ & $\begin{array}{c}\text { Post } \\
1\end{array}$ & $\begin{array}{c}\text { Post } \\
2\end{array}$ & $\begin{array}{c}\text { Post } \\
3\end{array}$ \\
\hline $\begin{array}{c}\text { Subject } \\
1\end{array}$ & 28 & 27 & 27 & 27 & 19 & 19 & 19 & 14 & 17 & - & 17 & 18 & 21 \\
\hline $\begin{array}{c}\text { Subject } \\
2\end{array}$ & 27 & 27 & 23 & 23 & 24 & 23 & 20 & 16 & 13 & 12 & 13 & 13 & 13 \\
\hline
\end{tabular}

Category:

$\begin{array}{ll}\text { Low } & =9-12 \\ \text { Bit low } & =13-17 \\ \text { Medium } & =18-22 \\ \text { Little high } & =23-27 \\ \text { High } & =\geq 28\end{array}$

Based on table 1. The math anxiety level category of subject 1 in the first pre-test is in the high category, then in pre-test 2 and 3, it is in the rather high category. In the first session, the subject 1 category of math anxiety is still in the rather high category. Then in the second to fourth sessions, it decreased and was in the medium category, in the fifth and sixth sessions it fell back into a rather low category. For session 7 no measurements were taken because the experiment with the music counselling approach only amounted to 6 sessions. Then in the condition without the first treatment or post-test 1 it is in the rather low category, then in the second and third untreated conditions, there is an increase in math anxiety in the moderate category. Whereas for subject 2, the first pre-test to the third treatment session was in the rather high category. In the fourth to the sixth session, it decreased to a rather low category, and in the last treatment session, it was in a low category. Meanwhile, the results of the work alliance measurement are presented in table 2.

Table 2. Measurement of Work Alliance

\begin{tabular}{cccccccc}
\hline & $\begin{array}{c}\text { Session } \\
\mathbf{1}\end{array}$ & $\begin{array}{c}\text { Session } \\
\mathbf{2}\end{array}$ & $\begin{array}{c}\text { Session } \\
\mathbf{3}\end{array}$ & $\begin{array}{c}\text { Session } \\
\mathbf{4}\end{array}$ & $\begin{array}{c}\text { Session } \\
\mathbf{5}\end{array}$ & $\begin{array}{c}\text { Session } \\
\mathbf{6}\end{array}$ & $\begin{array}{c}\text { Session } \\
\mathbf{7}\end{array}$ \\
\hline $\begin{array}{c}\text { Subject } \\
\mathbf{1}\end{array}$ & 29 & 29 & 39 & 41 & 40 & 41 & - \\
\hline $\begin{array}{c}\text { Subject } \\
\mathbf{2}\end{array}$ & 51 & 56 & 56 & 59 & 60 & 60 & 60 \\
\hline
\end{tabular}

Category :

High $=44-60$

Medium $=28-43$

Low $=12-27$

Based on the measurement results of the work alliance, it was found that the working alliance category of the implementation of counselling with the music approach was included in the medium category. For the category of work alliance, the implementation of counselling 
with a cognitive behaviour therapy falls into the high category. Furthermore, the effects of cognitive behaviour therapy and music counselling are presented in Figures 1 and 2.

Figure 1. Treatment Effects of Cognitive Behaviour Therapy

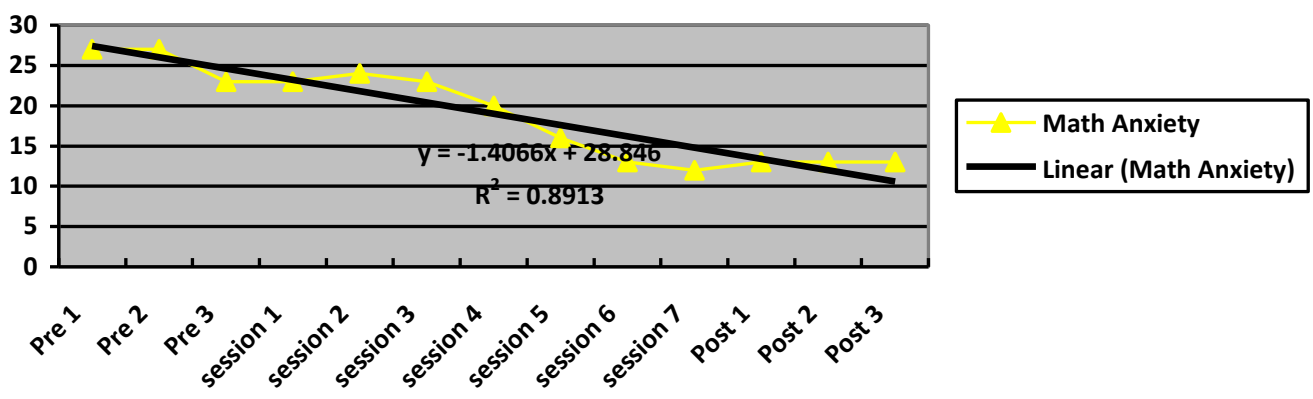

Figure 2. Effects of Music Counselling Treatment.

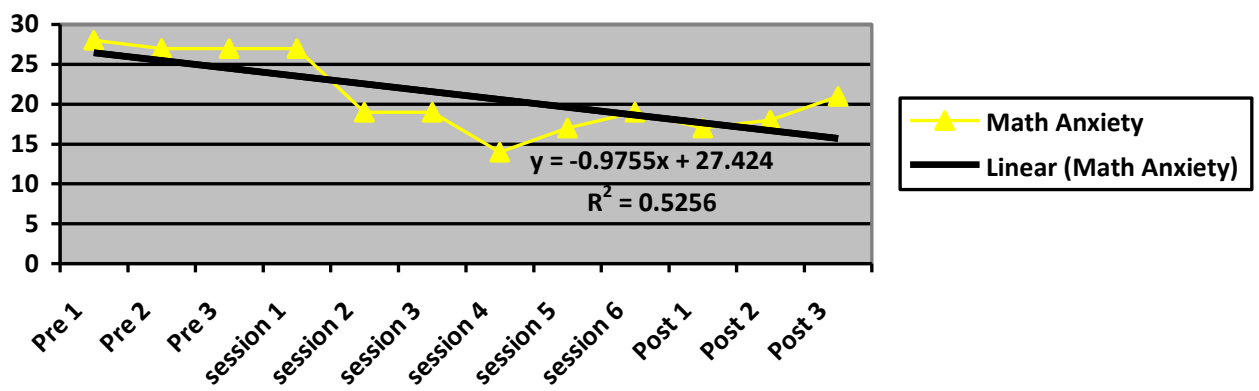

Based on the results of the treatment in Figure 1, cognitive behaviour therapy has an effect of $89.13 \%$ on reducing the subject's math anxiety. There was a decrease in the level of anxiety from the pre-test to the post-test mash. Then, the effect of music counselling treatment in Figure 2, namely music has an effect of $52.56 \%$ on the decrease in mathematics anxiety in the subject, there is a decrease in anxiety levels from the pre-test to the post-test period. Furthermore, to test the difference between the pre-test and the treatment period is presented in Table 3.

Table 3. Difference Test

\begin{tabular}{ccc}
\hline No. & Difference Test & $\mathrm{p}$ \\
\hline 1 & Pre-test with the Cognitive Behavior Therapy Period & 0.049 \\
\hline 2 & Pre-test with a period of non-treatment Cognitive Behavior & 0.034 \\
\hline 3 & Therapy & 0.018 \\
\hline 4 & Pre-test with the Music Counselling Treatment Period. & 0.046 \\
\hline 5 & Test the mean difference in the subject before receiving \\
treatment & 0.292 \\
\hline 6 & Period Without Treatment (Post-test) Cognitive Behavior & 0.037 \\
\hline
\end{tabular}

Based on table 3 Column 1. p-value $0.049<0.05$, which means that there is a significant difference in the math anxiety level of the subject before receiving treatment with the time when receiving treatment. Furthermore, based on table 3 column 2, the p-value of 
the pre-test score with the period without cognitive behavioural therapy p $0.034<0.05$, which means that the effect of cognitive behaviour therapy still has a therapeutic effect when the research subject has not received treatment. Based on this, it shows the results that the duration of the disorder recurrence of the subjects who received cognitive behaviour therapy did not occur significantly within 3 weeks after receiving the treatment. Furthermore, the results of the analysis of music counselling treatment are presented.

Based on the analysis of table 3 . Column 3 found a p-value $0.018<0.05$, which means that there is a significant difference in the level of math anxiety of the subject before receiving music counselling treatment with the music counselling treatment period. This shows that there is a significant effect of music counselling treatment on the reduction of the math anxiety level of the research subject. For the analysis of the difference test, the level of pre-test math anxiety with the untreated period (posttest) is presented in column 4.

Based on the analysis presented in column 4 , it is found that the p-value coefficient is $0.046<0.05$. Based on these coefficients, it can be concluded that there is a significant difference between the pre-test scores and the untreated mass scores. This indicates that the duration of the disruption recurrence of the subjects who received the music counselling treatment did not occur significantly within 3 weeks of measurement. Furthermore, presented the results of the analysis of the pre-test period difference between the subjects receiving the music counselling treatment and the subjects receiving the cognitive behavioural counselling treatment. Based on column 5 analysis, it was found that the p-value was 0.292>0.05, which means that there was no significant difference in the level of math anxiety of the subject before being given treatment.

Based on column 6 , it is found that the p-value is $0.037<0.05$, which means that there is a significant difference in the therapeutic effect of cognitive behaviour therapy and music counselling when the research subjects are in the untreated period. This shows that cognitiv behavioural therapy has a more significant effect on preventing the recurrence of math anxiety disorder in students who are the research subjects. Apart from using statistical data, this study also uses qualitative data. The following is presented with qualitative data.

Based on the results of the interview without treatment of cognitive behavioural therapy in three different times, it was found that the results of the analysis after the individual received cognitive behaviour therapy and entered the period without treatment, the individual who was the subject of the study experienced only a little feeling of anxiety when thinking about the math test to be carried out the next day. After attending counselling, the subjects studied did not experience any bad feelings at all when taking tests in mathematics lessons. Then related to the feelings that arise when it comes to math assignments, the subject feels a little bad when doing math assignments. When it comes to taking a math quiz in a hurry, subjects who have received cognitive behaviour therapy have very few bad feelings. When using mathematical tables, individuals feel no bad feelings at all. When having to watch the teacher explain the material or give examples of solving math problems, the individual does not feel bad at all. Then when listening to explanations in mathematics, the subjects receiving cognitive behaviour therapy did not feel bad at all, and when they saw or listened to their friends working on math problems, the individual did not feel bad at all. Even when it comes to starting a new chapter in maths lessons, individuals receiving cognitive behavioural therapy also don't feel bad at all. This shows that there is a significant effect of cognitive behaviour therapy on math anxiety experienced by research subjects.

Based on the results of interviews with subjects receiving music counselling treatment in three different times, it was found that the results of the analysis, after the individual received music treatment and entered a period without treatment, the individual who became the research subject experienced feelings of worry when thinking about the math exam that will be carried out the next day. Individuals experience tense feelings when they have to take 
tests in maths lessons. Then individuals who were given music counselling felt the role of worry and even nausea when they had to do math assignments. When given a quiz suddenly, the individual experiences a feeling of tension, and when the individual uses a mathematical table, the individual experiences a feeling of tension. Then when the individual in question sees the teacher explaining the material regarding mathematics, the individual feels calmer and it is easier to grasp the explanation from the teacher concerned. Meanwhile, when the individual listens to mathematical explanations, the individual experiences a feeling of calm and easily captures the explanation. Then when the individual concerned had to see or listen to other students explain solving math problems, the individual receiving the music treatment experienced a feeling of calm. But when it comes to starting a new chapter in maths lessons, the individual receiving the music treatment experiences a tense feeling.

Math anxiety is defined as feelings of tension, anxiety, or even fear that interfere with numbers and math-related problem solving (Westfall, McAuley, \& Millar, 2020). In addition, individuals who experience math anxiety are characterized by negative self-talk that they cannot control (Godbye dalam (Saputra, 2017). Math anxiety has two aspects, namely: anxiety when taking mathematics lessons and anxiety when participating in evaluations (tests, quizzes, or exams) of mathematics lessons (Paechter, Macher, Martskvishvili, Wimmer, \& Papousek, 2017). The factors that trigger math anxiety consist of math exams that must be followed, the number of formulas that must be learned, and the negative stigma that mathematics is a difficult subject (Anditya \& Murtiyasa, 2016a). cognitive behaviour therapy (CBT) is counselling based on a strategic cognitive, belief, and behavior formula for the characteristics of a particular disorder (Beck, 2011). The goal of cognitive behaviour therapy (CBT) is to turn dysfunctional thoughts and behaviours into functional thoughts and behaviours, which will have an impact on more positive feelings and the individual's ability to act as they should (Beck, 2011). While the techniques of cognitive behavioural counselling include reframing, confrontation, cognitive restructuring, self-management and relaxation (Efford, 2016). Whereas music counselling is defined as a healing instrument that involves the use of music and the clinical, educational, and social scope of the counselee or counselee who needs treatment, education or intervention in social and psychological aspects (Odell Miller, 2019).

The purpose of music counselling is related to the experience of meaning and beauty expressed through tone, matters related to music. Music is a historical phenomenon that exists in every culture and is universal because every culture has music with its own characteristics that are used for traditional purposes, and healing is an aspect of the traditions that exist in human culture. Meaning in music may on the one hand be a construct in a specific context (local, relative, subjective, and stylistic); on the other hand it may be embedded in the music in a universal, objective, independent context. Meaning in music can be understood both as a result of meaning: the meaning produced as a result of therapy; as a process: therapy is the process of creating or changing meaning, or as communication: the meaning of music is negotiated in interaction and dialogue (Odell Miller, 2019). Music counselling helps counselees or individuals obtain meaning through activities that use music, in addition to the interactions that occur in music counselling sessions, the counselee will find problems through self-expression using music.

Furthermore, this research was conducted online, in Indonesia itself, online counselling has only been known since the emergence of applications that use internet networks, such as Facebook, Skype, WhatsApp, Twitter zoom, line, email, and the like (Pasmawati, 2016). Reviewing the definition of counselling is a process of offering help by means of an interview by an expert (called a counsellor) to an individual who is experiencing problems (called a counselee) which leads to problem-solving that helps the problematic individual or counselee (Prayitno dan Amti dalam (Ifdil \& Zadrian, 2013). The effectiveness 
criteria used in this study consisted of the duration of the disorder recurrence and the level of work alliance between the counsellor and the counselee. The duration of recurrence is related to how long the effect of the intervention on the recurrence of the disorder experienced by the counselee. Whereas work alliances are related to the quality of the relationship between counsellors and counselees contributing to the success or success of the counselling being carried out. The working alliance between the counsellor and the counselee refers to the quality and strength of the collaborative relationship between the counsellor and the counselee in the counselee. This concept includes positive affective bonds between client and therapist, such as mutual trust, liking, respect, and concern. The alliance also includes more cognitive aspects of the counselling relationship, agreement on the objectives of counselling and a commitment to be actively involved in each counselling session that is undertaken (Cautin \& Lilienfeld, 2015)

Referring to research findings that show a significant reduction in math anxiety, this proves that cognitive behavioural therapy and music counselling have an effect on reducing the disorder. The application of cognitive behavioural therapy can be used before learning activities or math tests, using relaxation techniques, self-talk, and confrontation of dysfunctional thoughts. Meanwhile, music counselling can be used before class or during a math test. Before the lesson or test takes place, it can be started with musical activities such as playing a song that has been agreed upon to overcome anxiety, while in order to carry out the test or learning the teacher can play music like the flow of barock during learning tests to reduce anxiety.

Judging from the factors that cause math anxiety such as math exams, difficult and many formulas, and assumptions about difficult math lessons. Cognitive behaviour therapy works to address the symptoms and root causes of math anxiety experienced by the subject in question. With relaxation techniques, the subject is helped to overcome the symptoms of tension, dizziness, and heart palpitations. These results are reinforced by the results of research which found a significant effect of relaxation techniques to reduce blood pressure in individuals with hypertension (Aritonang, 2020). Meanwhile, reframing and cognitive restructuring techniques help individuals to overcome dysfunctional thoughts and wrong thought patterns that cause math anxiety. Reframing is a technique to help counselees open a more functional point of view in order to obtain a more constructive meaning of reality (Efford, 2016). Cognitive restructuring is a cognitive-behavioural flow technique that is used to correct the wrong mindset of the counselee and cause the individual to not function properly. Self-management techniques help individuals to empower and manage their potential in order to achieve the expected goals. Meanwhile, confrontation techniques help individuals to fight negative self-talk that arises when math anxiety hits them.

As for the effect of music counselling which is able to significantly reduce math anxiety, it is influenced by musical activists who are carried out by the research subject together with the counsellor during the treatment process. Music counselling will have a more significant impact if, in the process of implementing the counselling, the subject is invited to be actively involved. Active involvement, for example taking part in musical activities such as clapping hands, playing musical instruments, singing, or making songs (Djohan, 2006). In addition to the reduction in anxiety experienced by research subjects, the final result of this study is a song written by the subject and the counsellor. The research subjects wrote about their experiences with mathematics lessons in the form of song lyrics and the counsellor helped to make the tone for the lyrics. After the song was finished, the subject and the counsellor sang the song. Apart from composing songs, research subjects are also actively involved in other musical activities, such as singing their favourite songs and listening to songs such as over the rainbow, my heart will go on. After participating in the musical 
activity, it was found that the research subjects experienced a significant decrease in math anxiety.

Reviewing the treatment results with the effectiveness criteria used, it can be concluded that online cognitive behaviour therapy and music counselling are effective in reducing math anxiety. This can be seen from the different test of the level of math anxiety before receiving treatment with the treatment period which shows a $p$-value $<0.05$. Then for the duration of recurrence, the effect of the two counselling approaches also showed a significant reduction in math anxiety levels when the subject was in the untreated period. Judging from the existing work alliance, the cognitive behaviour therapy process shows a high level of work alliance, while the music counselling work alliance falls into the medium category. Then to compare which counselling is more effective, cognitive behaviour therapy has a more significant effect on preventing math anxiety disorder recurrence than music counselling.

Math anxiety relates to emotional, physical and cognitive aspects, referring back to the factors that cause math anxiety (Mammarella, Caviola, and Dowker, 2019). Triggers for math anxiety are influenced by exams, lots of formulas, and the assumption that math is a difficult subject. These factors refer to the cognitive aspects of students who take mathematics lessons, and cognitive behaviour therapy help overcome these factors. As for music counselling, musical activities experienced by individuals play a catalytic role or help individuals find the meaning of musical activities. Musical activity does not directly reduce the factors that cause math anxiety. Referring to this, the researchers predict that the therapeutic effect of cognitive behaviour therapy has a longer impact than music counselling.

Based on the research findings, it was concluded that cognitive behaviour therapy and music counselling were effective in reducing students' math anxiety. Cognitive behaviour therapy works to address the symptoms and root problems of math anxiety experienced by the counselee. Techniques in cognitive behaviour therapy affect many aspects such as feelings, thoughts, physical sensations, and actions. In music counselling, the lyrics and lyrics of the songs shift the focus of the individual who was originally fixated on the fear of facing math problems to become calmer during the math lesson. Furthermore, cognitive behaviour therapy is more effective than music counselling in preventing the recurrence of students' math anxiety.

\section{Conclusions and Suggestions}

Based on the research, it can be concluded that cognitive behaviour therapy and music counselling are effective in reducing students' math anxiety. Furthermore, cognitive behaviour therapy is more effective than music counselling, the implementation of cognitive behaviour therapy can be used before learning activities or math tests take place, and it affects various aspects such as feelings, thoughts, physical sensations, and actions.

For further researchers, it is recommended to study the same topic, but make observations and measurements with a longer susceptible time related to the duration of the recurrence of the disorder experienced by the study subjects. Because of this study, researchers only estimate the time for 3 weeks to measure the level of math anxiety of the subject after not receiving treatment.

\section{References}

Anditya, R., \& Murtiyasa, B. (2016a). Faktor-faktor penyebab kecemasan matematika. Paper presented at the Seminar Nasional Pendidikan Matematika, Surakarta. 
Anditya, R., \& Murtiyasa, B. (2016b). Faktor-faktor penyebab kecemasan matematika. Paper presented at the Seminar Nasional Pendidikan Matematika.

Aritonang, Y. A. (2020). Efektifitas teknik relaksasi nafas dalam terhadap tekanan darah pada pasien hipertensi di jakarta. Jurnal JKFT, 5(1), 41-47.

Azwar, S. (2012). Reliabilitas dan Validitas (4 ed.). Yogyakarta: Pustaka Pelajar.

Bazargan, M., \& Amiri, M. (2018). The effectiveness of modular cognitive behavioral therapy on mathematical anxiety and assertiveness in students. Journal of Fundamentals of Mental Health, 20(6).

Beck, J. S. (2011). Cognitif Behavior Therapy: Basic And Beyond. (2 ed.). New York: The Guilford Press.

Bicer, A., Perihan, C., \& Lee, Y. (2020). A Meta-Analysis: The Effects of CBT as a Clinic-\& School-Based Treatment on Students' Mathematics Anxiety. International Electronic Journal of Mathematics Education, 15(2). doi: https://doi.org/10.29333/iejme/7598

Cautin, R. L., \& Lilienfeld, S. O. (2015). The Encyclopedia of Clinical Psychology, 5 Volume Set: John Wiley \& Sons.

Djohan. (2006). Konseling musik: Teori dan Aplikasi. . Yogyakarta: Galangpress.

Efford, B. T. (2016). 40 Teknik Yang Harus Diketahui Setiap konselor (S. M. S. Helly Prajitno Soetjipto, Trans. 2 ed.). Yogyakarta: Pustaka Pelajar.

Febria, T. (2014). Penggunaan Konseling Musik Untuk Mengurangi Kecemasan Menyusun Skripsi Pada Mahasiswa BK UKSW. . Universitas Kristen Satya Wacana, Salatiga. Retrieved from http://repository.uksw.edu/handle/123456789/5541

Hakim, R. N. (2020). Rapat Terbatas, Jokowi Singgung Rendahnya Kemampuan Baca Siswa $R I$. Retrieved from https://nasional.kompas.com/read/2020/04/03/13291571/rapatterbatas-jokowi-singgung-rendahnya-kemampuan-baca-siswa-ri

Hopko, D. R., Mahadevan, R., Bare, R. L., \& Hunt, M. K. (2003). The abbreviated math anxiety scale (AMAS) construction, validity, and reliability. Assessment, 10(2), 178182.

Ifdil, \& Zadrian, A. (2013). Konseling Online Sebagai Salah Satu Pelayanan E-Konseling. Jurnal Konseling dan Pendidikan, 1(1).

Ikhsan, M. (2019). Pengaruh Kecemasan Matematis Terhadap Hasil Belajar Matematika. De Fermat: Jurnal Pendidikan Matematika, 2(1), 1-6.

Juliyanti, A., \& Pujiastuti, H. (2020). Pengruh Kecemasan Matematis dan Konsep Diri terhadap Hasil Belajar Matematika Siswa. Prima: Jurnal Pendidikan Matematika, 4(2), 75-83.

Mammarella, I. C., Caviola, S., \& Dowker, A. (2019). Mathematics anxiety: What is known, and what is still missing (1 ed.). New York: Routledge. 
McLeod, J. (2016). Pengantar Konseling: Teori dan Studi Kasus (A. K. Anwar, Trans. 4 ed.). Jakarta: Prenadamedia Group.

Munder, T., Wilmers, F., Leonhart, R., Linster, H. W., \& Barth, J. (2010). Working Alliance Inventory-Short Revised (WAI-SR): psychometric properties in outpatients and inpatients. Clinical Psychology \& Psychotherapy: An International Journal of Theory \& Practice, 17(3), 231-239.

Odell Miller, H. (2019). A Comprehensive Guide to Music Therapy: Theory, Clinical Practice, Research and Training. London: Jessica Kingsley Publishers.

Paechter, M., Macher, D., Martskvishvili, K., Wimmer, S., \& Papousek, I. (2017). Mathematics anxiety and statistics anxiety. Shared but also unshared components and antagonistic contributions to performance in statistics. Frontiers in psychology, 8, 1196.

Pasmawati, H. (2016). Cyber Counseling Sebagai Metode Pengembangan Layanan Konseling Di Era Global. Jurnal Ilmiah Syi'ar, 16(2), 34-54. doi: DOI 10.29300/syr.v16i2.1269

Prahara, H. (2017). Pada 2020, Tak ada Lagi Pelajaran Matematika di Negara ini. Retrieved from https://edukasi.kompas.com

Putri, I. (2018). Efektivitas Cognitive Behaviour Therapy dengan Teknik Self-Management untuk Mengurangi Kecemasan Menghadapi Pelajaran Matematika Peserta Didik Kelas VII SMPN 11 Bandar Lampung Tahun Pelajaran 2017/2018. UIN Raden Intan Lampung.

Saputra, P. R. (2017). Kecemasan Matematika dan Cara Menguranginya (Mathematic Anxiety and How To Reduce It). PYTHAGORAS: Jurnal Program Studi Pendidikan Matematika, 3(2).

Sukmadinata, N. S. (2012). Metode penelitian pendidikan.

Susanti, D. W., \& Rohmah, F. A. (2012). Efektivitas musik klasik dalam menurunkan kecemasan matematika (math anxiety) pada siswa kelas XI. HUMANITAS (Jurnal Psikologi Indonesia), 8(2), 129-142.

Tarigan, S. R. (2016). Efektivitas Terapi Musik Bagi Siswa SD Terhadap Kecemasan Belajar Matematika Kelas V SD Negeri No. 060886 dan 060889 Medan. Universitas Sumatera Utara, Medan. Retrieved from http://repository.usu.ac.id/handle/123456789/60652

Utami, H. (2017). Keefektifan Layanan Terapi Kelompok Teknik Kognitif Restrukturing dan Teknik Desensitisasi Sistematis untuk Mereduksi Kecemasan Akademik Siswa SMA Negeri 9 Palembang. . Universitas Negeri Semarang., Semarang. Retrieved from http://lib.unnes.ac.id/26873/1/full.pdf

Westfall, R. S., McAuley, A. J., \& Millar, M. (2020). The Influence of Implicit Math Anxiety on Math Achievement. Psychological Reports, 0033294120964055. 
Yuspitasari, R., \& Dalimunthe, R. Z. (2020). The Effect of Using Music Classic (Mozart) towards Student Anxiety Before The Exams. Journal of Family Sciences, 5(1), 47-56.

Yusuf, S., \& Nurihsan, A. J. (2019). Landasan bimbingan dan konseling. Bandung: Program Pasca Sarjana UPI dan PT. Remaja Rosdakarya. 